Borneo Journal of Sciences and Technology, Volume (2), Issue (1), Pages: 41-47

DOI: https://doi.org/10.35370/bjost.2020.2.1-08

e-ISSN: 2672-7439

(C) 2018, UCTS Publisher.

Submitted: $3^{\text {rd }}$ October 2019

Accepted: $4^{\text {th }}$ November 2019

Published: $31^{\text {th }}$ January 2020

\title{
Rhizophora apiculata: Comparative Properties Between Solid and Engineered Laminated Boards
}

\author{
Nasihah Mokhtar, Razak Wahab, Mohamad Saiful Sulaiman, Ros Syazmini Mohd Ghani \\ and Taharah Edin \\ University College of Technology Sarawak, 96000 Sibu, Sarawak, Malaysia.
}

\begin{abstract}
The study investigated the elucidation properties between the solid wood and engineered laminated boards of matured Rhizophora apiculata. Harvested logs segregated into the bottom, middle and top portions and subsequently sawn into wooden planks. The samples for laminated boards were cut into specific thicknesses and bonded with adhesive using pressed clamped. Preparation for testing samples for the solid and laminated boards made following the International Organization for Standardization (ISO) and American Society for Testing and Materials (ASTM) standards. Properties such as the moisture content, density, basic density, static bending (MOR and MOE), and compression were determined. The results showed an improvement in properties from the solid to laminated board. The values in density, MOR, and MOE increases in the range of 2-6\%, 29-42\%, and 13-36\%, respectively. However, values in the moisture content, basic density, and compression indicated vice versa trend ranging from $1-2 \%, 2-6 \%$, and $8-24 \%$, respectively. The bottom portion was more durable and robust compared than other portions.
\end{abstract}

Keywords: Rhizophora apiculata, solid wood, laminated wood, physical and mechanical properties.

\section{INTRODUCTION}

Mangrove forests inhabited the coastal and riverine shores of the tropics and sub-tropics [1];[2];[3] and constituted a dominant coastal vegetation community in tropical Asia where Malaysia-Indonesia is the centre of distribution [4]. Seventy species of mangrove plants distributed worldwide and divided into 20 genera [5]. According to [6], Rhizophora apiculata is a species of plant in the Rhizophoraceae family. The main agroforestry uses from this species are soil stabilization, coastal protection, wildlife/marine habitat for marine fauna and also as timber products which are fuelwood, charcoal, dyes, and traditional medicines [7];[8]. Nowadays, mangrove species can be further enhanced in constructions of dwellings, making furniture, rafts, boats, fences and even as a dying agent from the extracted tannin [9].

Economically the mangroves forests consist of both monetary and non-monetary such as forest industry, fisheries industry, wildlife conservation, tourism and environment protection [3];[10]. The most typical representatives' species in the mangrove forest are the Rhizophora apiculata, Rhizophora mucronata and Rhizophora mangle [11]. The mangrove trees is a complex combination of roots, trunk, branches and leaves [1], the trees can grow up to 30 metres in height with trunk diameters up to 0.5 metres in width, ellipticshaped leaves stained dark green with simple green in the middle and reddish-brown at the base of the leaves, bisexual flowers, round-shaped fruit up to pearl-shaped and brown, $18-38 \mathrm{~cm}$ long and $1-2 \mathrm{~cm}$ wide [12]. On properties perception, wood density is a critical characteristic defining the mechanical properties of the wood and its performance with high wood density has been found to decrease vessel implosion by reducing the mechanical stresses associated with the negative pressure in the water column during drought [13]. Greenwood of the mangrove $R$. apiculata trunk possesses higher density than water, but dry mangrove wood with a lower density floats in seawater and resistance to the marine deterioration [1].

Wood and modified wood-based materials have long been used in many applications due to their excellent features in aesthetic appearance, reasonable cost, ease of use, low density, high mechanical strength, etc. [14]. Excellent mechanical properties enable them to be utilized in a broad range of products especially after undergoing modification in the production of layered (laminated) wood with better strength or bending properties [15]. Wood laminating materials are obtained by bonding two or more layers with adhesive and joining the fibre directions of the layers parallel or perpendicular to each other [16]. Laminating is a 
technique that improves the value of the wood material while enabling changes in the wood's properties and can be altered via in various ways which comprise multiple layers of wood, most frequently in the form of veneers (thin slices), glued and pressed together [15]. The established laminated products which are oriented strand board (OSB), laminated veneer board (LVL), Strand-based composites include parallel strand board (PSL), laminated strand board (LSL) and oriented strand board (OSL), and also Glue-laminated timber (GLULAM) [17];[18];[19]. The study was focusing on the strength of physical and mechanical properties via solid wood and laminated wood. The differences properties between portions (bottom, middle, and top) investigated.

\section{MATERIALS AND METHODS}

\section{Sample Preparation}

The Rhizophora apiculata used in this study harvested from a mangrove forest in Inanam, Sabah. The mangrove trees chosen have an average height of $15 \mathrm{~m}$ and a diameter of $20 \mathrm{~cm}$ at $\mathrm{dbh}$ level. The trees cut from the bottom to the first branch (harvesting measurement on $30 \mathrm{~cm}$ from ground level). The logs then cross-cut into three (3) portions namely, the bottom, middle and top portions. The bottom portions were cut $50 \%$ of the total length of the logs, middle portions $30 \%$ and top portions $20 \%$. Subsequently, the samples will be cut to the size required for physical and mechanical testing and provided inappropriate conditions. This study, the samples divided into two groups consisting of solidwood and laminated wood.

The samples were cut by using a band saw into specific sizes and thickness (as followed standard requirement; for solid wood). For laminated wood, the samples with specific thickness were bonded together to perform as laminated wood. PVC glue branded, Pye Bond used for the process. Samples were conditioning for 48 hours using clamping jig to maintain the position and apply the pressure. The samples were conducted as followed by the International Organization for Standardization, ISO 3131-1975 [20];[21] and the American Standard Testing Method, ASTM D 143 for mechanical testing [22].

The test is conducted according to the standard specification, International Organization for Standardization, Wood-determination of Density of Physical Test, ISO 3131-1975 [20];[21]. The physical tests carried out are moisture content, density and basic density.

\section{Moisture Content}

The test is carried out according to the International Organization for Standardization which is ISO/TR 22157 [23]; [24], the method that was used to determine the moisture content based on oven-dry weight. In this study, the samples were cut following the indicator of $25 \mathrm{~mm} \times 25 \mathrm{~mm} \times 25 \mathrm{~mm}$ with weight approximately $1-8 \mathrm{~g}$.

\section{Determination of Density and Basic Density}

Density defined as the mass per unit volume, which is moisture content of sample, at $12 \%$. Basic density is defined as the mass per unit volume in oven-dry condition [20];[23]. Samples of size $10 \mathrm{~mm}$ x 30mm x $30 \mathrm{~mm}$ were taken and oven-dried for 48 hours at $105 \pm 2{ }^{\circ} \mathrm{C}$ to attain a constant weight. The samples were then weighed to give the oven-dried weight. The green volume, the samples were placed in water under a vacuum of about $700 \mathrm{~mm} \mathrm{Hg}$ for 24 hours until thoroughly saturated. The volume of the fully saturated samples was then obtained using the water displacement method.

\section{Mechanical Test}

The mechanical tests carried out are according to standard specifications, American Standard Testing Method, Standard Test Methods for Mechanical Properties of Wood-based Structural Material, ASTM D 143-2 [25];[26];[27] with modification. Two tests carried out were static bending tests and compression tests in parallel with the grain. The machine used to test the sample is the Universal Testing Machine (UTM). Before the mechanical testing, labelled timber samples will be kept at a standard temperature of $20 \pm 2^{\circ} \mathrm{C}$ and $65 \pm 5 \%$ Relative Humidity $(\mathrm{RH})$ or at least in a cold room and uniform temperature.

\section{Statistical Analysis}

Results presented as a mean \pm standard error. The statistical analyses of experimental findings based on the one-way Analysis of Variance (ANOVA). A significant difference was statistically considered at the level of $\mathrm{P}<0.05$. All experiment were triplicated $(n=3)$.

\section{RESULTS AND DISCUSSION}

\section{Investigate of Moisture Content}

Three (3) types of physical tests conducted on mangrove samples prepared in two groups, which is group 1 (sample in solid-state) and group 2 (sample in double-layer laminate). Physical properties were the 
moisture content (\% MC), density $\left(\mathrm{g} / \mathrm{cm}^{3}\right)$ and basic density $\left(\mathrm{g} / \mathrm{cm}^{3}\right)$.

Overall the result for moisture content highlighted bottom sample has an average of $46.83 \%$ moisture content and is the highest percentage. The average of moisture content at the middle portion indicated to $44.08 \%$. The lowest percentage of moisture content shown at the top portion with $42.76 \%$. The graph of moisture content in sample group 2 (double-layer laminate conditions) indicated a similar trend. The highest percentages of moisture content highlighted at bottom with $46.22 \%$, followed by the middle and top portion with $43.35 \%$ and $42.47 \%$, respectively. The statistical analysis (Table 1) highlighted there are no significant differences between the portions (bottom, middle, and top) to both groups (solid and laminated).

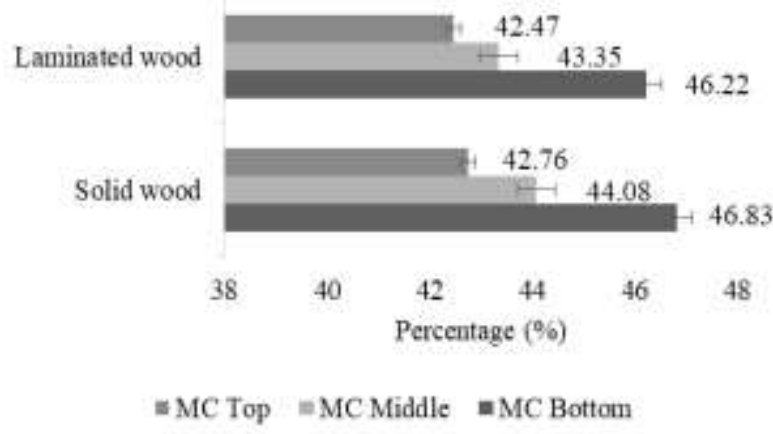

Figure 1: Moisture content for solid wood and laminated wood due to the different portion.

That result influence by different between trees and species or in the same tree. On a single tree, wood core moisture content or parts of each tree may be different. This may be due to the moisture content of the tree is influenced by the age of the tree, species, external factors such as the condition or area of growth of the tree and internal factors such as the structure of the wooden anatomy. Mangrove tree Rhizophora apiculata is a kind of tree where the base of the tree is soaked in a state of stagnant water all year round. The base part of the root, including the root is the closest part to the soil and serves to facilitate the absorption of water to other parts of the tree. Based on the results obtained, the bottom of mangrove trees has the highest percentage of moisture content compared to other parts, due to the presence of water around the habitat. Moisture content significantly affects the mass of the wood, its dimensions, volume, physical, and mechanical properties (strength), and its resistance to attacks by fungi, molds, and insects [28].

\section{Differentiation of Density and Basic Density}

Figure 2, the result in group 1 (solid) indicated the highest density at a bottom portion with $0.91 \mathrm{~g} / \mathrm{cm}^{3}$ and followed by the middle and top portion with $0.88 \mathrm{~g} / \mathrm{cm}^{3}$ and $0.86 \mathrm{~g} / \mathrm{cm}^{3}$, respectively. While in group 2 (laminated) highlighted that the density which are 0.93 $\mathrm{g} / \mathrm{cm}^{3}, 0.91 \mathrm{~g} / \mathrm{cm}^{3}$, and $0.83 \mathrm{~g} / \mathrm{cm}^{3}$ for the bottom, middle, and top, respectively. According to Table 1, statistical analysis shows there are not significantly different between the portions at group 1 (solid). There are significant differences between portions at group 2 (laminated) with value $\mathrm{p} \leq 0.05$.

Nevertheless, the graph indicated that the trend of basic density in group 1 (solid) decreasing from bottom to the top with $0.80 \mathrm{~g} / \mathrm{cm}^{3}, 0.76 \mathrm{~g} / \mathrm{cm}^{3}$, and $0.71 \mathrm{~g} / \mathrm{cm}^{3}$. While in group 2 (laminated), highlighted that the highest basic density at the bottom of $0.75 \mathrm{~g} / \mathrm{cm}^{3}$ followed by the middle and top portions with 0.74 $\mathrm{g} / \mathrm{cm}^{3}$ and of $0.68 \mathrm{~g} / \mathrm{cm}^{3}$, respectively. The statistical analysis (Table 1) shows there are significant differences between portion for both groups (solid group and laminated group) with value $\mathrm{p} \leq 0.05$.

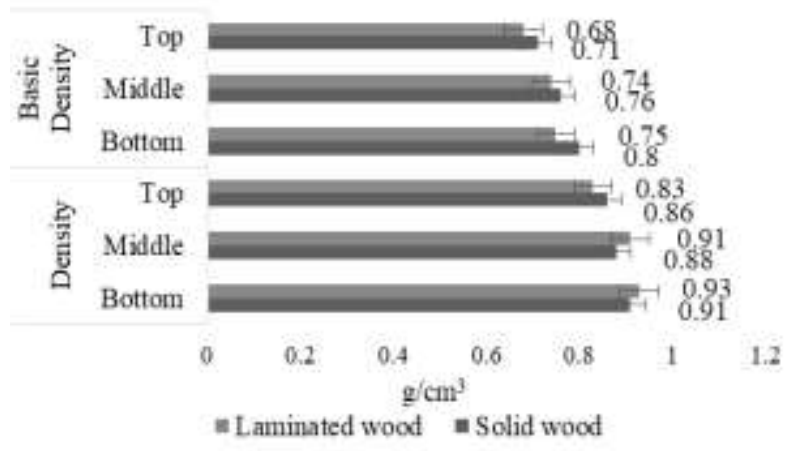

Figure 2: Density and basic density for solid wood and laminated wood due to the different portion

The difference in density of wood in parts is influenced by the structure of the wood anatomy, size and arrangement of cells, length and density of fiber, cell wall thickness and chemical content in the wood [29]. In addition, the moisture content in wood cells can affect the value of wood density, the specific gravity of wood, wood dimensions and other wood strengths. High moisture content increases the density value [30]. Based on the results obtained from the physical properties test, it can be explained that the laminated wood has slightly higher in density compared to the solid wood. The results supported by [14], highlighted that density of the laminated wood materials has more superior values than the solid wood materials which were representing their kinds. The increase is assumed to be due to glue usage and layered structure. 
Rhizophora apiculata: Comparative Properties Between Solid and Engineered Laminated Boards

Table 1: Data analysis for physical tests in group 1 (solid) and group 2 (laminated)

\begin{tabular}{lllllc}
\hline Group & $\begin{array}{c}\text { Tests } \\
\text { Type }\end{array}$ & $\begin{array}{c}\text { Sum of } \\
\text { square }\end{array}$ & Mean square & $\begin{array}{c}\text { P- } \\
\text { Value }\end{array}$ & $\begin{array}{c}\text { Sig. } \\
\text { level }\end{array}$ \\
\hline Solid & MC & 34.5386 & 17.2693 & 0.1448 & $\mathrm{~ns}$ \\
& Density & 0.0057 & 0.00288 & 0.1465 & $\mathrm{~ns}$ \\
& Basic & 0.0170 & 0.0085 & 0.0261 & $*$ \\
& Density & & & & \\
\hline Laminated & MC & 30.7368 & 15.3684 & 0.2981 & $\mathrm{~ns}$ \\
& Density & 0.0229 & 0.0114 & 0.0188 & $*$ \\
& Basic & 0.0110 & 0.0055 & 0.0124 & $*$ \\
& Density & & & & \\
\hline ** : significant at $P<0.01 ;$ & $*$ : significant at $P<0.05 ;$ & $n s$ \\
; not significant & & & &
\end{tabular}

\section{Determination of Modulus of Rupture (MOR) and Modulus of Elasticity (MOE) on Static Bending Test}

The result (Figure 3) in group 1 (solid) indicated that bottom portion has the highest MOR value with 168.20 $\mathrm{N} / \mathrm{mm}^{2}$ and followed by the top and middle portion which is $167.88 \mathrm{~N} / \mathrm{mm}^{2}$ and $165.28 \mathrm{~N} / \mathrm{mm}^{2}$, respectively. Whereas in group 2 (laminated), highlighted the trend of MOR value decreasing from bottom to the top, which are $284.83 \mathrm{~N} / \mathrm{mm}^{2}, 256.85$ $\mathrm{N} / \mathrm{mm}^{2}$ and $237.35 \mathrm{~N} / \mathrm{mm}^{2}$, respectively. There is no significant difference between portions in group 1 (solid) (see Table 2). While highlighted significant difference between portions in group 2 (laminated) with value $\mathrm{p} \leq 0.05$.

Figure 3 indicated the MOE in group 1 (solid) has a higher value on the bottom portion with 20330.81 $\mathrm{N} / \mathrm{mm}^{2}$ and followed by the top and middle portion which is $19744.86 \mathrm{~N} / \mathrm{mm}^{2}$ and $18208.88 \mathrm{~N} / \mathrm{mm}^{2}$, respectively. While in group 2 (laminated) highlighted the MOE value in decreasing order from bottom to the top, which is $27553.66 \mathrm{~N} / \mathrm{mm}^{2}, 24424.42 \mathrm{~N} / \mathrm{mm}^{2}$, and $22664.09 \mathrm{~N} / \mathrm{mm}^{2}$, respectively. Nevertheless, (Table 2) the statistical analysis in group 1 (solid) and group 2 (laminated) highlighted there is no significant difference between a portion ( $\mathrm{p} \geq 0.05)$.

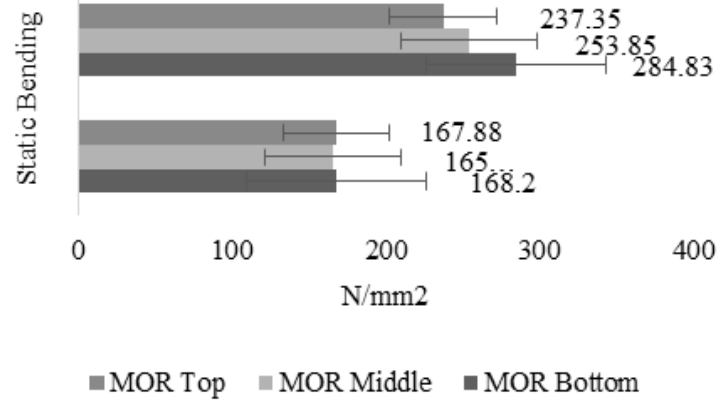

Figure 3: Modulus of rupture for static bending test on solid wood and laminated wood due to the different portion

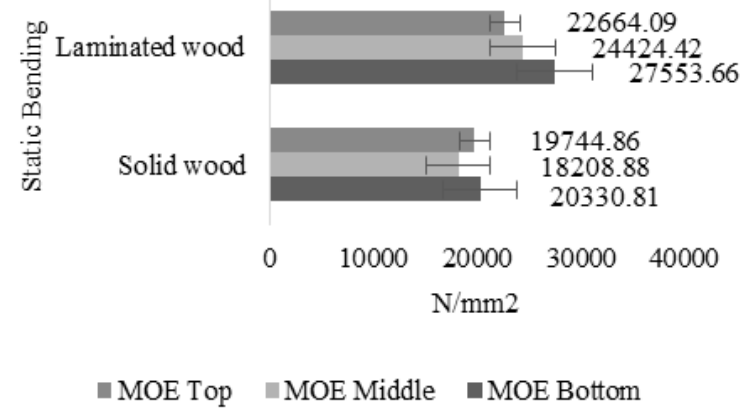

Figure 4: Modulus of elasticity for static bending of solid and laminated wood at a different portion

The factors that influence the evaluation of wood strength is density. The mechanical characteristics or wood strength, such as static wood bending are closely related to the density of the wood [31];[32]. The static flexural strength of the wood will increase by increasing the density from the base to the top. It can be explained that the base portion of mangrove trees Rhizophora apiculata has the highest static bending test value also has the highest density value. The strength of wood is also influenced by other factors such as genetics, tree parts, presence of timber knots, wooden anatomy structures, length and density of cells, tree age or species [29];[33]. 
Rhizophora apiculata: Comparative Properties Between Solid and Engineered Laminated Boards

Table 2: Table 1: Data analysis for static bending tests in group 1 (solid) and group 2 (laminated).

\begin{tabular}{llcccc}
\hline Group & Test & $\begin{array}{c}\text { Sum of } \\
\text { square }\end{array}$ & $\begin{array}{c}\text { Mean } \\
\text { square }\end{array}$ & $\begin{array}{c}\text { P- } \\
\text { Value }\end{array}$ & $\begin{array}{c}\text { Sig. } \\
\text { level }\end{array}$ \\
\hline Solid & MOR & 20.5617 & 10.2808 & 0.945 & $\mathrm{~ns}$ \\
& MOE & 4.9065 & 2.45325 & 0.616 & $\mathrm{~ns}$ \\
& Compression & 65.838 & 32.919 & 0.2301 & $\mathrm{~ns}$ \\
& & & & & \\
\hline Laminated & MOR & 4647.43 & 2323.72 & 0.0289 & $*$ \\
& MOE & 9.60688 & 4.80344 & 0.155 & $\mathrm{~ns}$ \\
& & & & & \\
& Compression & 472.178 & 236.089 & 0.0007 & $* *$ \\
& & & & & \\
\hline
\end{tabular}

** : significant at $P<0.01 ; \quad *$ : significant at $P<0.05 ; n s$; not significant

\section{Determination of Compression Test}

Figure 5 shows the highest value of compression on group 1 (solid) at a bottom portion with $71.59 \mathrm{~N} / \mathrm{mm}^{2}$ and followed by the top and middle portion with respectively around $68.72 \mathrm{~N} / \mathrm{mm}^{2}$ and $65.86 \mathrm{~N} / \mathrm{mm}^{2}$. While group 2 (laminated) indicated that the compression value decreasing from bottom to the top portion with $65.96 \mathrm{~N} / \mathrm{mm}^{2}, 64.65 \mathrm{~N} / \mathrm{mm}^{2}$, and 52.05 $\mathrm{N} / \mathrm{mm}^{2}$. The statistical analysis result (Table 2) highlighted that there are no significant differences between portions in group 1 (solid). While group 2 (laminated) indicated that there are significant differences between portions with value $\mathrm{p} \leq 0.01$.

The higher density as an important factor that influences the results. Mechanical characteristics or wood strength such as wood compression strength are closely related to the density of wood in which the density of wood is an important feature in determining the strength of a tree [32];[34]. The compressive strength of the wood will increase with increasing density from the base to the top. Thus, it can be explained that the $R$. apiculata mangrove root base has the highest compression test value also has the highest density value. However, the strength of wood is also influenced by internal factors such as genetics, tree parts, presence of timber book, wood anatomy structure, length and density of cells, tree age or species and external factors such as growth areas [29].

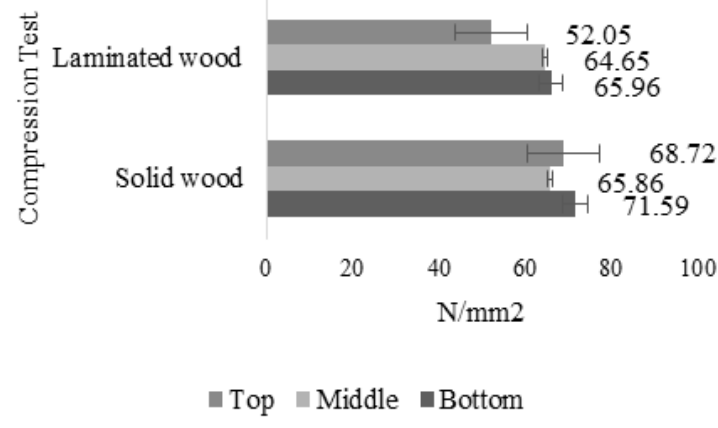

Figure 5: Compression test on solid wood and laminated wood due to the different portion.

\section{CONCLUSION}

Results of the study on different properties from matured Rhizophora apiculata indicated an improvement in the physical and mechanical properties from solid to the engineered laminated wood.

In the physical properties, the moisture content highlighted that the decreasing order from bottom to the top and from solid wood to the laminated wood in the range $1-2 \%$. Density indicated an increase in values from solid to the laminated wood with a variety of around $2-5 \%$ while the basic density shows the vice versa results in a variation of 2-6\%.

In the mechanical properties, the static bending highlighted the MOR and MOE value improved the strength from solid to the laminated by the range 29$42 \%$ and $13-26 \%$, respectively. The compression strength, however, shows the solid wood are stronger compared than laminated wood with a range of around $8-24 \%$.

The study also found that the bottom portion indicated the highest value in physical and mechanical testing.

The factor that influence of results may be due to the natural morphological in $R$. apiculata with content, high fibre strength and also complex microstructure at the bottom portion.

\section{ACKNOWLEDGEMENT}

This study financed by the University College of Technology Sarawak Grant (UCTS/RESEARCH /4/2017/01). The authors expressed their gratitude to University College of Technology Sarawak (UCTS) and Forest Research Institute Malaysia (FRIM) for permission on using their laboratory and workshop equipment in the preparation and analysis parts of the study. 
Rhizophora apiculata: Comparative Properties Between Solid and Engineered Laminated Boards

\section{REFERENCES}

[1] Zhang, X., Chua, V.P., Cheong, H.T. (2015). Hydrodynamics in mangrove prop roots and their physical properties. Journal of hydro-environment research. 9(2):281-294. DOI: 10.1016/j.jher.2014. 07.010 .

[2] González, N.S.S. (2012). Structure and function of wood in mangroves. Thesis in Doctor of Philosophy at the University of Queensland.

[3] Chandra, I.A., Seca G., and Abu Hena, M.K. (2011). Aboveground Biomass Production of Rhizophora apiculate Blume in Sarawak Mangrove Forest. American Journal of Agricultural and Biological Sciences 6 (4): 469474.

[4] Abdullah, F., Shaari, H., Satyanarayana, B., Khalik, W.M.A.W.M., Jaafar, M.Z.M. (2018). Macro, Micro, and Non-Essential Elements in Different Parts of Rhizophora Apiculate. Malaysian Journal of Analytical Sciences, 22(4): 570 - 578. DOI: 10.17576/mjas-2018-2204-01

[5] Spalding, M., Kainuma, M. and Collins, L. (2010). World atlas of mangroves. Earthscan, London.

[6] Duke, N. C. 2006). Rhizophora apiculata, $R$. mucronata, $R$. stylosa, R. X Annamalai, $R . X$ lamarckii (Indo-West Pacific stilt mangrove).

[7] Alongi, D. M. (2008). Mangrove forests: resilience, protection from tsunamis, and responses to global climate change. Estuarine, Coastal and Shelf Science, 76(1), 1-13.

[8] Mazda, Y., Wolanski, E., Ridd, P.V., (2007). The Role of Physical Processes in Mangrove Environments: Manual for the Preservation and Utilization of Mangrove Ecosystems. Terrapub, Tokyo, $598 \mathrm{pp}$.

[9] Nabihah. A (2015). Bioactivities of Methanol Extracts from Rhizophora apiculata Blume and Rhizophora mucronata Lam. Barks. BSc. Thesis. Universiti Malaysia Sarawak (UNIMAS). (Unpublished).

[10] Bennet, E.L. and C.J. Reynold, 1993. The value of a mangrove area in sarawak. Biodiversity Conservation, 2: 359-375. DOI:10.1007/BF0011 4040

[11] Halim, N.H.A., Abidin, N.A.Z., and Me, R. (2013). A Study of Chemical Compounds in Rhizophora apiculata. The Open Conference Proceedings Journal, 2013(4), (Suppl-2, M24) 108-110.

[12] Sugiarto, A. (2019). Supplemental materials for preprint: Pertumbuhan Akar Propagul Rhizophora apiculate Blume Pada Medium Air Tawar. Retrieved from osf.io/krpa.

[13] Santini, N.S., Schmitz, N., Bennion, V., and Lovelock, C.E. (2013).The anatomical basis of the link between density and mechanical strength in mangrove branches. Functional Plant Biology, 2013, 40, 400-408. doi.org/10.1071/FP12204.

[14] Percin, O., Sofuoglu, S.D., Altunok, M. (2015). Effect of Heat Treatment on Some Physical and Mechanical Properties of Laminated Wood. The XXVII International Conference Research for Furniture Industry, Ankara, Turkey.

[15] Gáborík, J., Gaff, M., Ruman, D., Záborský, V., Kašičková, V., and Sikora, A. (2016). Adhesive as a Factor Affecting the Properties of Laminated Wood. Adhesive \& lamination, BioResources 11(4), 10565-10574. DOI: 10.15376/biores.11.4. 10565-10574

[16]Cibo, C., Altay, C., Özçifçi, A., Baysal, E., and Toker, H. (2018). Determination of Some Mechanical Properties of Laminated Wood Material Reinforced with Carbon Fiber (CFRP). Mesleki Bilimler Dergisi (MBD), 7 (2): 123 - 132

[17] Shmulsky, R., \& Jones, P. D. (2019). Forest products and wood science: an introduction. John Wiley \& Sons.

[18] Wiegner, K., Wilke, O., Jann, O., Brödner, D., Scheffer, H., Kalus, S., \& Till, C. (2009). Study on VOC-emissions from oriented strand boards (OSB). In Proceedings of the 9th International conference Healthy Buildings.

[19] Ong, C. B. (2015). Glue-laminated timber (Glulam). In Wood Composites (pp. 123-140). Woodhead Publishing.

[20] Sulaiman, M.S., Ramle, S.F.M., Hashim, R., Sulaiman, O., Amini, M.H.M., Geng, B.J. (2018). The classical mechanics engineered of Bambusa vulgaris and Schizostachyum brachycladum. Journal of Tropical Resources and Sustainable Science 6:57-61.

[21] Wahab, R., Rasat, M.S.M., Samsi, H.W., Mustafa, M.T., \& Don, S.M.M. (2017a). Assessing the suitability of Agro-Waste from Oil Palm Empty Fruit Bunches as Quality Eco-Composite Boards. Journal of Agricultural Science 9 (8): 237-247. ISSN 1916-9752 E-ISSN 1916-9760. Doi: 10.5539/jas. v9n6p251. Published by Canadian Center of Science and Education.

[22] Ghani, R.S.M., Wahab, R., Azmi, S.N.B., Wi, K.M., Mokhtar, N., Sulaiman, M.S. (2018a). Comparison of Properties between Solid and Laminated Mahang Wood. Advanced Journal of Technical and Vocational Education, 2(2): 24-28.

[23]Wahab, R., Mokhtar, N., Ghani, R.S.M., Sulaiman, M.S., \& Samsi, H.W. (2018a). Changes in Strength Characteristics and Durability on 4Year-Old Tropical Bamboo Gigantochloa Scortechinii through Heat Treatment. Asian Journal of Science and Technology, 9(5):82278233. 
Rhizophora apiculata: Comparative Properties Between Solid and Engineered Laminated Boards

[24] ISO / TR 22157. (2004). Bamboo: Determination of Physical and Mechanical Properties.

[25] Wahab, R., Sulaiman, M.S., Mokhtar, N., Ghani, R.S.M., Samsi, H.W., \& Yusuf, M. (2018b). Properties of Hibiscus cannabinus and Elaeis guineesis fronds fibers Eco-Composites boards. International Journal of Current Research 10 (5): 69770-69775. ISSN: 0975-833X.

[26] Khalid, I., Sulaiman, O., Hashim, R., Wahab, R., Jumhuri, N., \& Rasat, M.S.M. (2015). Evaluation on Layering Effects and Adhesive Rates of Laminated Compressed Composite Panels made from Oil Palm (Elaeis guineesis). Journal of Materials and Design. 68: 24-28. DOI:10.1016 / j.matdes. 2014.12.007, Elsevier Science Direct UK.

[27] Anonymous. (1974). The Strength Properties of Timber. MTP Construction. England: Medical and Technical Publishing Co. Ltd.

[28] Wałach, D., Jaskowska-Lemańska, J., Dybeł, P. (2015). The impact of the moisture content of wood on the results of non-destructive tests. Forestry and Wood Technology № 92: 448-454.

[29]Desch H.E. (1989). Struktur, Sifat dan Penggunaan. Terjermah oleh Mohd. Zin Jusoh and Mohd. Hamami Sahri. Edisi ke enam. United Kingdom: The Macmillan Press.
[30] Thelandersson, S., \& Larsen, H.J. (2002). Timber Engineering. John Wiley \& Sons, Ltd

[31] Rasat, M.S.M., Wahab, R., Sulaiman, O., Janshah M., Aminuddin M., Tamer A. T. and Izyan K. (2011). Properties of bio-composite board from oil palm frond agricultural waste. Bioresources Journal 6(4): 4389-4403. Sep. 2011.

[32] Haygreen, J.G. and Bowyer, J.L. (1930). Introduction to Forest Product and Wood Science, Subtitled by Suhaimi Muhammed and Sheikh Abdul Karim Yamani Zakaria. Ampang Press Sdn. Bhd., Kuala Lumpur.

[33] Khalid, I., Razak, W., Mahmud, S., Othman, S., Affendy, H., Hanim, R.A. \& Andy, R.M. (2010). Chemical Changes in 15-year-old Cultivated Acacia hybrid Oil-Heat Treated at 180, 200 and $220^{\circ}$ C. International Journal of Chemistry 2 (1). Pp. 97-107. Feb. 2010. ISSN: 1916-9701. Canadian Center of Science and Education.

[34] Wahab, R., Ghani, R.S.M., Samsi, H.W., \& Rasat, M.S.M. (2017b). Changes in the Features of Oil Heat Treated 18-Years Old Acacia mangium. Research Journal of Pharmaceutical, Biological and Chemical Sciences 8 (2): 2093-2106. ISSN: 0975-8585 